UDK 811.163.42’374:316.647.8

Izvorni znanstveni rad

Rukopis primljen 3. III. 2021.

Prihvaćen za tisak 21. V. 2021.

doi.org/10.31724/rihjj.47.2.14

\title{
Milica Mihaljević
}

Institut za hrvatski jezik i jezikoslovlje

Ulica Republike Austrije 16, HR-10000 Zagreb

orcid.org/0000-0002-9348-8177

mmihalj@ihjj.hr

\section{MUŠKO I ŽENSKO U HRVATSKOME JEZIKU I LEKSIKOGRAFIJI - STEREOTIPI I JEZIČNA DISKRIMINACIJA}

U radu ${ }^{1}$ se analiziraju stereotipi u hrvatskome jeziku, nazivlje spolne/rodne(ne)diskriminacije, strategije postizanja spolno/rodno nediskriminirajućega jezika u kojemu su na najmanju mjeru svedeni spolni/rodni stereotipi i predrasude te je prikazan odraz takvoga pristupa na leksikografsku obradu u e-rječniku (na primjeru Mrežnika) i terminološkoj bazi (na primjeru Jene). Istraživanje se temelji na korpusnoj analizi triju hrvatskih korpusa ( $h \mathrm{rWaC}$, Hrvatska jezična riznica i Jezikoslovni korpus), koji su pretraživi u Sketch Engineu. U radu se pokazuje 1. da se nazivlje i strategije za postizanje spolno/rodno nediskriminirajućega hrvatskog jezika razlikuju od nazivlja i strategija koji se primjenjuju u engleskome i nekim drugim jezicima, 2. da je izgradnja mocijskih profesijskih naziva katkad teška i izvornim govornicima hrvatskoga jezika, 3. da se izgradnja spolno/rodno nediskriminirajućega i uključivoga jezika u kojemu su stereotipi svedeni na najmanju moguću mjeru zrcali i u e-leksikografskoj obradi u nekoliko polja rječničkoga/terminološkoga članka.

\section{Uvod}

Stereotipi su duboko ukorijenjeni u jeziku i oni snažno odražavaju stavove, jezično ponašanje i percepciju sebe i drugih. Stereotipi i predrasude neodvojiv su dio identiteta, ali i rezultat interakcije socijalnih, kulturnih, psiholoških i jezičnih čimbenika. Jezik diskretno reproducira društvenu asimetriju u statusu i

\footnotetext{
1 Rad je izrađen na istraživačkome projektu Hrvatski mrežni rječnik - MREŽNIK (IP-2016-06-2141) i projektu Hrvatsko jezikoslovno nazivlje - Jena (Struna-2017-09-05), koje u cijelosti financira Hrvatska zaklada za znanost i koji se provode u ustanovi nositelju projekta Institutu za hrvatski jezik i jezikoslovlje, i na internome projektu Instituta za hrvatski jezik i jezikoslovlje Muško i žensko u hrvatskome jeziku.
} 
moći, što se odražava i u odgovarajućim društvenim ulogama ${ }^{2}$. U terminološkoj bazi Hrvatskoga jezikoslovnog nazivlja - Jena ${ }^{3}$, koja je podbaza terminološke baze Struna ${ }^{4}$, stereotipi su definirani kao ustaljeni i uopćeni vrijednosni sudovi pojedinca ili zajednice o pojedinačnim pojavama, pojedincima ili društvenim skupinama. Stereotipi se dijele na društvene i jezične stereotipe. ${ }^{5}$ U Jeni je društveni stereotip određen kao prototip kojim određeni stereotip prihvaćamo kao tipični slučaj te se njime koristimo pri brzim prosudbama, najčešće ljudi. Društveni su stereotipi u cjelini vlasništvo društva čiji identitet grade bez obzira na individualne razlike u mišljenju (Miloš 2014: 13). Jezični je stereotip riječ ili izraz kojim se u jeziku izražava ustaljen i uopćen vrijednosni sud govornika neke jezične zajednice o pojedinačnim pojavama, pojedincima ili društvenim skupinama. Jezični su stereotipi najčešće povezani s izražavanjem odnosa prema određenim društvenim skupinama ili pojedincima (etnički ili spolni/rodni stereotipi), zanimanjima, zemljopisnim područjima (gradovima, državama), ljudskim osobinama, životinjama i sl. Mocijski odnosi (muško-ženski parnjaci) ${ }^{6}$, sažeti jezični oblici poput frazema ${ }^{7}$, poslovica i viceva ${ }^{8}$ najčešći su jezični ostvaraji stereotipnih odnosa. Do stereotipa se dolazi procesom stereotipizacije. ${ }^{9}$

Spolni/rodni stereotipi uloge su koje su pridružene muškarcima i ženama od najranijega djetinjstva preko obrazaca ponašanja koji su im nametnuti. Oni se odražavaju u vjerovanjima o osobinama muškaraca i žena i dovode do očekivanja o tome kakvi su oni i kakvi bi trebali biti. ${ }^{10}$ Podskupina spolnih/rodnih stereotipa kojima će u ovome radu biti posvećena posebna pozornost profesijski su stereotipi ${ }^{11}$.

\footnotetext{
2 „Language powerfully reflects and influences attitudes, behaviour and perceptions.” (Menegatti i Rubini 2017).

3 Više o Jeni vidi u Mihaljević, Hudeček i Jozić 2020, Hudeček i Mihaljević 2020a.

4 Više o bazi Struna vidi u Nahod 2020.

5 U Jeni su ti stereotipi navedeni kao podređeni nazivi.

6 „Analiza mocijskih naziva posebno je aktualna jer se o njoj najčešće govori u kontekstu seksizma u jeziku, seksističke uporabe jezika, androcentrizma u jeziku i feminističke lingvistike te se kao primjer jezične diskriminacije navode oblici naziva za zanimanja i titula.” (Mihaljević i Štebih Golub 2009: 82).

7 O muškarcima i ženama u frazemima vidi u Kovačević 2019, 2020.

8 O stereotipima u poslovicama i vicevima vidi u Miloš 2014, 2017.

9 Hrvoja Heffer razlikuje proces stereotipizacije (nastanak, rađanje stereotipa kroz jezično-društvene okolnosti) i proces stereotipiziranja (praktična primjena udomaćenih stereotipa u komunikacijskoj praksi) (2007: 170).

10 „Gender stereotypes are beliefs about the attributes of men and women and produce expectations about what they are like and should be like." (Menegatti i Rubini 2017).

11 Na potrebu posebnoga istraživanja profesijskih stereotipa u ruskome jeziku upućuje Elena Vilinbakhova (2014: 235): „For Russian linguists, a possible topic for further investigation are professional stereotypes. Significant changes in Russian reality in the past twenty years have given rise to big changes in the social
} 


\section{Metodologija, korpus i hipoteze}

Istraživanje provedeno u ovome radu temelji se na korpusnoj analizi triju hrvatskih korpusa koji su pretraživi u Sketch Engineu ${ }^{12}$. To su općejezični korpusi $H r-$ vatski mrežni korpus - hrWaC i Hrvatska mrežna riznica te terminološki korpus znanstvenih tekstova iz područja jezikoslovlja Jezikoslovni korpus ${ }^{13}$, koji je izrađen u sklopu projekta Hrvatsko jezikoslovno nazivlje - Jena. Osim primjera pronađenih u tim korpusima analizirat će se i drugi primjeri dostupni na internetu. Za provedenu su analizu posebno važne skice riječi i razlikovne skice riječi u Sketch Engineu. Analizirane su i mrežne stranice Gender-neutral Language in the European Parliement, Gender Equality Law Center, Gender-sensitive Communication, Guidelines for Nonsexist Language in APA Journals, Portrayal Guidelines for Gender Balanced Representation, United Nations Human Rights, editage Insights, Pojmovnik rodne terminologije, Zakon o ravnopravnosti spolova i Ženska soba. Jezik ravnopravnosti. Kako bi se jasnije osvijetlili problemi spolno/rodno nediskriminirajućega, uključivoga i neutralnoga jezika i leksikografije, bilo je potrebno na početku istraživanja provesti terminološku analizu.

Polazne su hipoteze u ovome radu: 1. nazivlje i strategije za postizanje spolno/ rodno nediskriminirajućega hrvatskog jezika razlikuju se od nazivlja i strategija koji se primjenjuju u engleskome, koji može biti i spolno/rodno neutralan jezik, i nekim drugim jezicima, 2. izgradnja mocijskih profesijskih naziva katkad je teška i izvornim govornicima hrvatskoga jezika, pa su, da bi se to postiglo, nužni savjeti jezikoslovaca, 3. izgradnja spolno/rodno nediskriminirajućega jezika, u kojemu su stereotipi svedeni na najmanju moguću mjeru, odražava se i u e-leksikografskoj obradi u nekoliko polja rječničkoga/terminološkoga članka.

\section{Stereotip u hrvatskim korpusima}

Skice riječi u hrvatskim korpusima pokazuju raspodjelu kolokacija riječi stereotip prikazanu u Tablici 1.

system. People have changed their attitudes to some traditional professions (it shows up in euphemisms like cleaning manager instead of cleaner), and many new professions have appeared. Hence, it might be interesting to analyze how these changes have become represented in the Russian language."

12 Više o Sketch Engineu, skicama riječi i razlikovnim skicama riječi vidi u Kilgarriff i dr. 2004.

13 O Jezikoslovnome korpusu vidi Marković, Mihaljević i Mihaljević 2020, Marković i Mihaljević 2020. 
Tablica 1. Skice riječi stereotip u hrvatskim korpusima

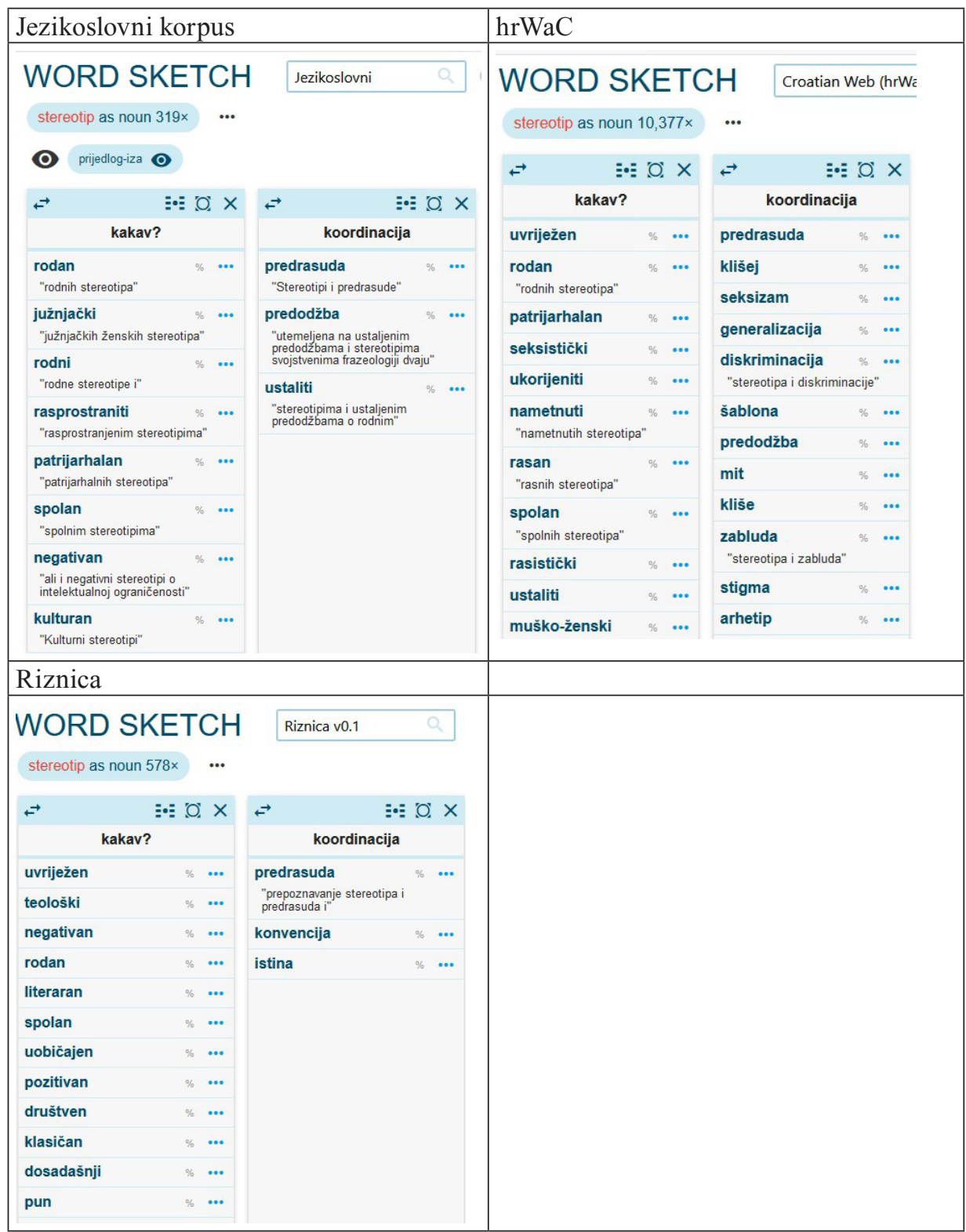

Pregledamo li kolokacije riječi stereotip u hrvatskim općejezičnim ( $h r W a C, R i$ znica) i specijaliziranim korpusima (Jezikoslovni korpus), možemo zaključiti: 
1. U svim pregledanim korpusima naziv stereotip najčešće se pojavljuje u koordinaciji s riječju predrasuda.

2. U svim korpusima najčešće se pojavljuju kolokacije koje upućuju na to da je riječi o spolnim/rodnim stereotipima: rodan (riječ je o pogrešnoj lematizaciji, treba biti rodni), rodni, patrijarhalan, seksistički, spolni, muško-ženski.

3. Osim stereotipa koji upućuju na muško-ženske odnose, u korpusu se pojavljuju i ovi stereotipi: kulturni, rasni/rasistički, teološki, društveni.

Glavne su značajke stereotipa prepoznate u korpusima: rasprostranjenost, uvriježenost, negativnost, uobičajenost. U daljnjoj analizi pozornost će biti usmjerena spolnim/rodnim stereotipima kao najčešćim stereotipima koji su duboko ukorijenjeni u jeziku, a često se zrcale i u leksikografskim (e-leksikografskim) djelima.

\section{Nazivlje spolne/rodne (ne)diskriminacije}

„Diskriminacija u jeziku postoji na svim jezičnim razinama, od jezičnih seksizama koji prenose duboko ukorijenjene predrasude o ženama do potpune isključenosti žena iz jezika. Da bi se razumjela (ne)prisutnost žena ili pak njihova diskriminirana prisutnost u jeziku, treba razumjeti odnose moći i rodnu problematiku i koristiti i stvarati jezik koji ne diskriminira žene." (Pomovnik rodne ideologije 2007: 20).

Kako bi se uspostavilo spolno/rodno nediskriminirajući, neseksistički jezik, teži se smanjivanju spolnih/rodnih stereotipa ${ }^{14}$. Na engleskome se govornom području pojavio niz novih naziva. Često je riječ o bliskoznačnicama (npr. gender discriminatory language, sexist language ${ }^{15}$ ), istoznačnicama (gender-neutral language, gender-blind language) ili nazivima koji se u različitim izvorima upotrebljavaju u različitome značenju, tj. kao istoznačnice ili kao bliskoznačnice

14 Usp. „Gender-fair language (GFL) aims at reducing gender stereotyping and discrimination.” (Sczesny, Formanowicz i Moser 2016: 1).

15 „Sexist language is the same as gender-discriminatory language. However there is a subtle difference in how people use the terms: sexist language is commonly seen as language that the user intends to be derogatory; gender-discriminatory language, on the other hand, also includes language people use without any sexist intention." (Gender-sensitive Communication). 
(gender-sensitive language, gender-neutral language, gender-inclusive language, gender-free language, gender-fair language $e^{16}$, gender biased language, gender discriminatory language; gender senistive language, gender non-discriminatory language). Neki su nazivi u antonimnome odnosu (gender discriminatory language - gender non-discriminatory language; gender-neutral language - gender specific language), a drugi u hijerarhijskome odnosu (gender-discriminatory language - gender-biased language). Neki od tih naziva već su obrađeni u Jeni, a za druge se s pomoću terminoloških načela ${ }^{17} \mathrm{u}$ ovome radu predlažu hrvatski nazivi. Pri izgradnji nazivlja spolne/rodne (ne)diskriminacije polazni su izvori bili Pojmovnik rodne terminologije iz 2007. godine i Jezikoslovni korpus. Međutim, mnogi razmatrani nazivi ne nalaze se u tim izvorima. Neki su prikupljeni s engleskih mrežnih stranica, a neki su bili predmetom upita poslanih na adresu jezičnoga savjetnika u Institutu za hrvatski jezik i jezikoslovlje (npr. gender diversity). U Tablici 2 naveden je engleski naziv, prijedlog definicije na hrvatskome jeziku i prijedlog hrvatskoga naziva.

Tablica 2. Nazivlje spolne/rodne (ne)diskriminacije

\begin{tabular}{|l|l|l|}
\hline engleski & definicija & hrvatski \\
\hline gender analysis & $\begin{array}{l}\text { analiza razlika u uvjetima, potrebama, } \\
\text { stupnju sudjelovanja u različitim područji- } \\
\text { ma života, pristupu izvorima, nadzoru nad } \\
\text { sredstvima, donošenju odluka i slično koje } \\
\text { postoje između muškaraca i žena u odnosu } \\
\text { na njihove dodijeljene spolne/rodne uloge }\end{array}$ & spolna/rodna analiza \\
\hline $\begin{array}{l}\text { gender biased lan- } \\
\text { guage }\end{array}$ & $\begin{array}{l}\text { jezični izraz koji namjerno ili nesvjesno štiti } \\
\text { ili omalovažava jedan spol/rod (najčešće } \\
\text { ženski) te je stoga vrsta spolno/rodno diskri- } \\
\text { minirajućega jezika }\end{array}$ & $\begin{array}{l}\text { spolno/rodno pristran } \\
\text { jezik }\end{array}$ \\
\hline $\begin{array}{l}\text { gender discrimina- } \\
\text { tory language }\end{array}$ & $\begin{array}{l}\text { jezični izraz koji, iako bi se trebao odnositi } \\
\text { na sve ljude, nenamjerno isključuje jedan } \\
\text { spol/rod ili implicira da je jedan spol/rod } \\
\text { superioran drugomu }\end{array}$ & $\begin{array}{l}\text { spolno/rodno diskrimi- } \\
\text { nirajući jezik }\end{array}$ \\
\hline gender diversity & $\begin{array}{l}\text { jednaka zastupljenost svih spolova/rodova u } \\
\text { nekoj skupini (na poslu, u školi i slično) }\end{array}$ & $\begin{array}{l}\text { ravnomjerna zastuplje- } \\
\text { nost spolova/rodova }\end{array}$ \\
\hline
\end{tabular}

\footnotetext{
16 Nazivi su navedeni u radu Omrčen 2017.

17 Pri odabiru hrvatskoga nazivlja spolne/rodne (ne)diskriminacije posebno su bitna bila načela davanja prednosti domaćemu nazivu i načelo davanja prednosti kraćemu nazivu. O terminološkim načelima vidi Hudeček i Mihaljević 2012.
} 


\begin{tabular}{|c|c|c|}
\hline gender identity & osobna svijest o svojemu spolu/rodu & spolni/rodni identitet \\
\hline $\begin{array}{l}\text { gender neutral lan- } \\
\text { guage }\end{array}$ & $\begin{array}{l}\text { jezični izraz u kojemu se govori o ljudima } \\
\text { općenito bez ikakvoga elementa koji bi } \\
\text { upućivao na njihov spol/rod. Napomena: U } \\
\text { istome se značenju upotrebljavaju i nazivi } \\
\text { gender-blind language i gender inclusive } \\
\text { language. }\end{array}$ & $\begin{array}{l}\text { spolno/rodno neutralan } \\
\text { jezik }\end{array}$ \\
\hline $\begin{array}{l}\text { gender non-discrimi- } \\
\text { natory language }\end{array}$ & $\begin{array}{l}\text { jezični izraz koji se odnosi na sve ljude, ne } \\
\text { isključuje jedan spol/rod ili ne implicira da } \\
\text { je jedan spol/rod superioran drugomu }\end{array}$ & $\begin{array}{l}\text { spolno/rodno nediskri- } \\
\text { minirajući jezik }\end{array}$ \\
\hline gender roles & $\begin{array}{l}\text { društvena uloga koja obuhvaća niz ponaša- } \\
\text { nja i stavova koji se smatraju prihvatljivim } \\
\text { za pojedini spol/rod }\end{array}$ & spolne/rodne uloge \\
\hline gender stereotype & $\begin{array}{l}\text { uopćeni pogled ili pretpostavka o osobina- } \\
\text { ma ili ulogama koje imaju ili bi trebali imati } \\
\text { žene i muškarci. Napomena: Spolni/rodni } \\
\text { stereotip štetan je kad ograničuje moguć- } \\
\text { nosti žena ili muškaraca da razviju svoje } \\
\text { osobne sposobnosti, ostvare se u karijeri } \\
\text { koju žele i odaberu ono što žele u svojemu } \\
\text { životu. }\end{array}$ & spolni/rodni stereotip \\
\hline gender stereotyping & $\begin{array}{l}\text { pridruživanje pojedinačnoj ženi ili muškar- } \\
\text { cu osobina ili uloga samo na temelju njihove } \\
\text { pripadnosti skupini žena ili muškaraca. } \\
\text { Napomena: Spolno/rodno stereotipiziranje } \\
\text { može dovesti do ugrožavanja ljudskih prava } \\
\text { i temeljnih sloboda }\end{array}$ & $\begin{array}{l}\text { spolno/rodno stereotipi- } \\
\text { ziranje }\end{array}$ \\
\hline gender-fair language & $\begin{array}{l}\text { jezični izraz koji teži smanjivanju jezičnih } \\
\text { stereotipa i diskriminacije. Napomena: } \\
\text { Smatra se da su dva osnovna načina sma- } \\
\text { njivanja jezičnih stereotipa i diskriminacije } \\
\text { neutralizacija i feminizacija. }\end{array}$ & $\begin{array}{l}\text { spolno/rodno pravedan } \\
\text { jezik }\end{array}$ \\
\hline $\begin{array}{l}\text { gender-inclusive } \\
\text { language }\end{array}$ & $\begin{array}{l}\text { jezični izraz koji se odnosi na sve ljude, koji } \\
\text { ne isključuje ni jedan spol/rod niti implicira } \\
\text { da je jedan spol/rod superioran drugomu }{ }^{18}\end{array}$ & $\begin{array}{l}\text { spolno/rodno uključiv } \\
\text { jezik }\end{array}$ \\
\hline $\begin{array}{l}\text { gender-sensitive } \\
\text { language }\end{array}$ & $\begin{array}{l}\text { jezični izraz u kojemu je izražena spolna/ } \\
\text { rodna jednakost }\end{array}$ & $\begin{array}{l}\text { spolno/rodno osjetljiv } \\
\text { jezik }\end{array}$ \\
\hline language sexisam & $\begin{array}{l}\text { diskriminacija na spolnoj/rodnoj osnovi koja } \\
\text { se provodi na jezičnoj razini }\end{array}$ & $\begin{array}{l}\text { spolna/rodna diskrimi- } \\
\text { nacija u jeziku }\end{array}$ \\
\hline
\end{tabular}

18 Vidi Sczesny, Moser i Wood 2015: 943-954. 


\begin{tabular}{|l|l|l|}
\hline sexist language & $\begin{array}{l}\text { jezični izraz koji, iako bi se trebao odnositi } \\
\text { na sve ljude, namjerno isključuje jedan spol// } \\
\text { rod ili implicira da je jedan spol/rod supe- } \\
\text { rioran drugomu. Napomena: Naziv spolno/ } \\
\text { rodno obilježen jezik bliskoznačan je nazivu } \\
\text { spolno/rodno diskriminirajući jezik, ali je } \\
\text { razlika u tome što se spolno/rodno obilježen } \\
\text { jezik uglavnom upotrebljava namjerno, a } \\
\text { spolno/rodno diskriminirajući jezik često se } \\
\text { upotrebljava nenamjerno. }\end{array}$ & \\
\hline stereotyped langu- \\
age & $\begin{array}{l}\text { jezik koji nudi stereotipiziranu sliku neke } \\
\text { skupine ljudi }\end{array}$ & stereotipizirani jezik \\
\hline
\end{tabular}

U gornjoj tablici ravnopravno su navedeni nazivi spol i rod. O tim je nazivima u hrvatskome jeziku i rječnicima analiza objavljena u radu Hudeček i Mihaljević 2019. ${ }^{18} \mathrm{U}$ tome je radu prikazana obrada tih naziva u hrvatskim rječnicima i u terminološkoj bazi podataka Struna. Za potrebe ovoga rada u Tablici 3 navode se samo neke definicije iz Strune (antropologija) koje ukazuju na značenje naziva rod i spol.

Tablica 3. Rod i spol u Struni (područje antropologije)

\begin{tabular}{|l|l|}
\hline rod & $\begin{array}{l}\text { kulturno specifično oblikovanje spolova i njihova međuodnosa Napomena: } \\
\text { Budući da je riječ o društvenoj konstrukciji koja obuhvaća djelovanje i uloge } \\
\text { pripisane muškarcima i ženama u javnome i privatnome životu u određenome } \\
\text { društvu, definicija roda promjenjiva je u vremenu i prostoru. Opreka između } \\
\text { roda kao sociokulturne i spola kao biološke kategorije posebno je važna za } \\
\text { feminističku antropologiju iako se mnogi antropolozi iz drugih područja s } \\
\text { njom ne slažu. Engleski: gender }\end{array}$ \\
\hline $\begin{array}{l}\text { rodna hijerar- } \\
\text { hija }\end{array}$ & $\begin{array}{l}\text { različito vrednovanje rodno obilježenih aktivnosti i svojstava s obzirom na } \\
\text { razdiobu resursa, ugleda i moć Napomena: Zbog nedovoljno jasnoga razdva- } \\
\text { janja uporabe naziva rod i spol, spolna hijerarhija često se upotrebljava kao } \\
\text { istoznačnica rodnoj hijerarhiji. Engleski: gender hierarchy }\end{array}$ \\
\hline rodni identitet & $\begin{array}{l}\text { društveno očekivano ponašanje i podjela rada s obzirom na rodnu pripadnost } \\
\text { pojedinaca. Engleski: gender role }\end{array}$ \\
\hline spol & $\begin{array}{l}\text { ukupnost bioloških obilježja po kojima se muškarac i žena razlikuju. Engle- } \\
\text { ski: sex }\end{array}$ \\
\hline
\end{tabular}

U toj je terminološkoj bazi navedena temeljna razlika između roda ('društvena konstrukcija') i spola ('biološka obilježja'), ali se navodi i da se mnogi antropolozi s tom podjelom ne slažu.

18 Pregled nastanka rodne lingvistike vidi u Pišković 2014, 2018. 
Riječ je o iznimno osjetljivome nazivlju, pa se ovdje navode neki argumenti o kojima treba voditi računa prije nego što se engleski gender dosljedno zamijeni s rod.

1. U engleskome jeziku riječ gender označuje i rod i spol. To se jasno vidi iz primjera navedenih u prijevodnoj memoriji (Englesko-hrvatski rječnik, Glosbe). Na Slici 1 navode se neki primjeri prijevoda sveze gender issues, a za potrebe ovoga rada analiza je prijevoda riječi gender na hrvatski šire provedena:

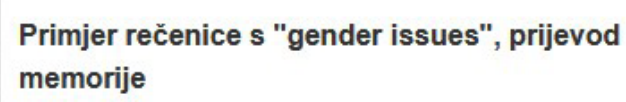

A variety of workshops are offered, such as on work-lifebalance or on gender issues.

Nude se radionice o brojnim temama, poput ravnoteže između poslovnog i privatnog života i rodnih pitanja.

- Council Regulation (EC) No 2836/98 of 22 December 1998 on integrating gender issues in development cooperation(7).

Uredba Vijeća (EZ) br. 2836/98 od 22. prosinca 1998. o uvođenju rodnih pitanja u razvojnu suradnju $\left(\frac{1}{2}\right.$ (7)

Gladly. if it means I don't have to listen to your automobile gender issues.

Rado, ako to znači da neću slušati o spolu automobila.

And I thought I had gender issues

A mislio sam da ja imam problema sa spolom.
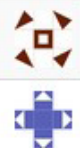

Slika 1. Prijevod na hrvatski sveze gender issues

2. Riječ gender u engleskome je višeznačna $i$ ta se višeznačnost u nekim svezama ne razrješuje ni kontekstom, nego tek definicijom, npr. razlika 
između naziva genderless language i gender neutral language, u kojima riječ gender ima posve drukčije značenje, kao što je vidljivo iz ovoga teksta: A genderless language is a natural or constructed language that has no distinctions of grammatical gender - that is, no categories requiring morphological agreement for gender between nouns and associated pronouns, adjectives, articles, or verbs. The notion of a genderless language is distinct from that of gender-neutral language, which is neutral with regard to natural gender. (Wikipedia, natuknica Genderless language).

3. Budući da hrvatski jezik ima gramatički rod, nije jezik koji nema rod (genderless langauge) ni jezik koji ima prirodni rod (natural gender language), nego je jezik koji ima gramatički rod (grammatical gender language), problemi koji se pojavljuju u engleskome mnogo su češći i vidljiviji u hrvatskome.

4. Engleska riječ sex višeznačna je i odgovara hrvatskim nazivima seks i spol. U engleskome se sve češće riječ sex u značenju spol zamjenjuje riječju gender ${ }^{19}$.

5. Riječ rod ima mnogo više značenja od riječi spol u hrvatskome jeziku i od riječi gender u engleskome, npr. u Školskome rječniku hrvatskoga jezika (Birtić i dr. 2012) riječ rod ima sedam značenja, a riječ spol samo jedno.

6. Iako se pridjev rodni u značenju 'koji se odnosi na rod, društveni konstrukt' često pojavljuje u nazivima i imenima, to nije slučaj s imenicom rod. Tako npr. na hrvatskome možemo govoriti o rodno osviještenoj politici, ali imamo samo politiku promicanja ravnopravnosti spolova (nikad rodova). Postoji Odbor za ravnopravnost spolova Hrvatskoga sabora (engl. Parliamentary Gender Equality Committee), koji bi se mogao zvati Odbor za rodnu ravnopravnost, ali ne i Odbor za ravnopravnost rodova, postoji pravobranitelj/ica za ravnopravnost spolova (engl. Gender Equality Ombudsperson), koja ne bi mogla biti pravobranitelj/ica za ravnopravnost rodova), Povjerenstvo za ravnopravnost spolova (engl. Committee for Gender Equality), a ne Povjerenstvo za ravnopravnost rodova), Nacionalna politika za promicanje ravnopravnosti spolova (ne rodova) itd. Pojmovnik rodne terminologije izdao je Ured za ravnoprav-

\footnotetext{
19 „....researchers feel that "gender" is more politically correct or less offensive than "sex" in scientific writing." (editage Insights).
} 
nost spolova. U uvodu toga pojmovnika piše: „U hrvatskoj jezičnoj praksi pojmovi rod i spol nisu dovoljno značenjski razdvojeni. Jedan od razloga je i ukorijenjena uporaba termina spol i u značenju roda." I u Pojmovniku se katkad upotrebljava dvostruki naziv rod/spol, npr. rodne/spolne uloge, statistika vođena prema spolu/rodu (engl. gender roles, gender statistics).

Sve navedeno ukazuje na to da bi u hrvatskome jeziku, u kojemu se tek pridjev rodni najčešće pojavljuje u značenju 'koji se odnos na društveni konstrukt', bolje i jasnije bilo uvesti novo značenje imenice spol (po potrebi označene i nekim pridjevom, npr. društveni spol, odabrani spol ili slično) nego izrazito višeznačne imenice rod. Ipak, zbog iznimne osjetljivosti toga pitanja u ovome se radu ravnopravno upotrebljavaju imenice rod i spol te pridjevi rodni i spolni.

\section{Strategije izbjegavanja diskriminacije i stereotipizacije}

Izbjegavanje predrasuda i stereotipa bitan je korak na putu prema spolnoj/rodnoj ravnopravnosti u svim područjima. Stoga postoje strategije za njihovo uklanjanje iz jezika (ili barem svođenje na najmanju mjeru).

Kako bi se postupalo prema pripadnicima svih spolova/rodova na jednak način, od 1980. radi se na uspostavljanju spolno/rodno neutralne uporabe jezika kako nijedan spol/rod ne bi bio doveden u (ne)povoljniji položaj te kako se ne bi produbljivale predrasude prema bilo kojemu spolu/rodu.

Načela spolne/rodne jednakosti, neutralnosti i nediskriminacije utemeljene na spolu/rodu ugrađena su u zakonodavstvo Europske unije (npr. Gender-neutral language in the European Parliement). Primjena načela spolne/rodne nediskriminacije u jeziku zahtijeva različite strategije u različitim jezicima, koje ovise o različitim jezičnim sustavima. Engleski ima prirodan rod i većina je imenica spolno/rodno neutralna. Hrvatski s druge strane ima gramatički rod i u njemu je svakoj imenici, posvojnoj i osobnoj zamjenici, pridjevu i nekim glagolskim oblicima pridružen rod. Stoga je u hrvatskome nemoguće upotrebljavati strategije spolne/rodne neutralnosti kao u engleskome, ali je moguće i potrebno izgrađivati spolno/rodno nediskriminirajući jezik. Često je iznimno teško preslikavati i engleske terminološke obrasce, kao što je prikazano u prethodnome poglavlju. Budući da se u hrvatskome često pokušava primijeniti iste strategije kao u en- 
gleskome ili u kojemu drugom velikom jeziku, ovdje ćemo ukratko navesti u čemu se one sastoje.

\subsection{Neutralizacija - uporaba spolno/rodno neutralnih profesijskih naziva}

Za jezike koji imaju prirodan rod kao što je engleski dokument Gender-neutral language in the European Parliement predlaže postupak neutralizacije. Tako se predlaže da se imenice koje u sebi sadržavaju sastavnice man, woman, master, mistress itd. ili imaju spolno/rodno obilježeni sufiks, npr. stuardess, zamijene imenicama koje takve značajke nemaju kako je prikazano u Tablici 4.

Tablica 4. Spolno/rodno obilježeni profesijski nazivi i spolno/rodno neobilježeni profesijski nazivi u engleskome

\begin{tabular}{|l|l|}
\hline spolno/rodno obilježeni nazivi & spolno/rodno neobilježeni nazivi \\
\hline businessman & business person \\
\hline cameraman/camerawoman & camera operator, camera crew \\
\hline chairman & chair, chairperson \\
\hline fireman & firefighter \\
\hline headmaster/headmistress & director, principal \\
\hline layman & layperson \\
\hline policeman/policewoman & police officer \\
\hline salesman & sales representative \\
\hline spokesman & spokesperson \\
\hline sportsman & athlete \\
\hline steward/stewardess & flightattendant \\
\hline weatherman & weather reporter / forecaster \\
\hline
\end{tabular}

Da bi se postigao spolno/rodno neutralan jezik, u engleskome je potrebno zamijeniti samo manji broj profesijskih imenica. Također se predlaže uporaba množine i zamjenice they umjesto he ili she, npr. Each athlete must have his accreditation on him at all times. $\checkmark$ All athletes are required to have their accreditation on them at all times (Portrayal guidelines for gender balanced representation). Katkad je nužno preoblikovati tekst tako da se upotrebljava imperativ ${ }^{20}$ ili pasiv kako se ne bi upotrijebila spolno/rodno obilježena zamjenica. Kad to nije moguće, dokument Gender-neutral language in the European Parliement pre-

\footnotetext{
20 I u hrvatskome uporaba imperativa ako se osobi obraćamo s Vi može dovesti do rodne neutralnosti rečenice.
} 
poručuje uporabu muških ili ženskih mocijskih parnjaka actor/actress, waiter/ waitress $^{21}$ ovisno o tome je li riječ o muškarcu ili ženi. Prema istome dokumentu nurse i midwife odnose se na osobe obaju spolova/rodova. Zbog analize jezične uporabe $\mathrm{u}$ hrvatskome jeziku posebno je važno da se $\mathrm{u}$ tome dokumentu navodi da rješenja koja smanjuju čitljivost teksta kao što su dvostruki oblici s/he ili him/ her treba izbjegavati. ${ }^{22}$

\subsection{Feminizacija - uporaba muških i ženskih profesijskih naziva}

U dokumentu Gender-neutral language in the European Parliement predlaže se da se u jezicima koji imaju gramatički rod ravnopravno stvaraju i upotrebljavaju muški i ženski mocijski nazivi, npr. Kanzlerin, présidente, sénatrice, assessora (2018: 5). Također se predlaže uporaba dvostrukih naziva umjesto generičkoga muškog roda, npr. tutti i consiglieri e tutte le consigliere (2018: 5). Time se ne stvara spolno/rodno neutralan jezik, ali se stvara nediskriminirajući jezik koji potiče spolnu/rodnu uključivost.

Hrvatski spada u jezike koji imaju gramatički rod te se spolna/rodna ravnopravnost može postići feminizacijom. Pritom treba voditi računa o ovim činjenicama:

1. tvorba ženskih (i rjeđe muških) profesijskih naziva često je izazovna i izvornim govornicima hrvatskoga jezika

2. usporedna uporaba muških i ženskih naziva često dovodi do sintaktičkih i semantičkih nejasnoća te smanjuje razumljivost i čitljivost teksta

3. izvorni govornici hrvatskoga jezika često ne znaju kad treba upotrijebiti ženski, a kad muški profesijski naziv ${ }^{23}$.

\footnotetext{
21 „Actor is now commonly used for both genders; use actress if the person's gender is relevant.” (Genderneutral language in the European Parliement 2018: 12-13).

22 „Solutions that reduce the readability of a text, such as combined forms ('s/he','him/her'), should be avoided." (Gender-neutral language in the European Parliement 2018: 79).

23 Stoga govornici hrvatskoga jezička često traže savjet koji se odnosi na tvorbu ili uporabu mocijskih parnjaka.
} 


\subsubsection{Stereotipi i mocijski parnjaci u hrvatskome jeziku}

Mocija, mocijska tvorba, mocijski parnjaci i muško-ženski odnosi u hrvatskome jeziku bili su predmetom analize u mnogim jezikoslovnim radovima i jezičnim savjetnicima ${ }^{24}$. Iscrpan popis nalazi se na stranici projekta Muško $i$ žensko u hrvatskome jeziku.

Rječnik ravnopravnosti, koji se nalazi na stranicama Ženske sobe, izrađuje se metodom masovne podrške (engl. crowd sourcing), te pri njegovoj izradi može svatko sudjelovati. U Tablici 5 navode se neki primjeri profesijskih naziva iz toga rječnika kako bi se dokazala hipoteza da je tvorba mocijskih parnjaka izazov i za izvorne govornike hrvatskoga jezika. Navedeni su predloženi standardnojezični nazivi prema tražilici sastavljenoj na projektu Muško $i$ žensko u hrvatskome jeziku.

Tablica 5. Muški i ženski profesijski nazivi iz Rječnika ravnopravnosti

\begin{tabular}{|l|l|l|}
\hline $\begin{array}{l}\text { muški mocij- } \\
\text { ski parnjak }\end{array}$ & ženski mocijski parnjak & $\begin{array}{l}\text { predloženi } \\
\text { standardnojezični nazivi }{ }^{25}\end{array}$ \\
\hline ronilac & $\begin{array}{l}\text { ronilkinja, roniteljica, roniljka, ronion- } \\
\text { kinja }\end{array}$ & ronilac/roniteljica \\
\hline dadiljac & dadilja & dadilja (m/ž) \\
\hline rudar & rudarka & rudar/rudarica \\
\hline praljac & pralja & perilac/pralja \\
\hline drvosječa & drvosječica, drvosječina & drvosječa (m/ž) \\
\hline pisac & piskinja & pisac/spisateljica \\
\hline vodič & vodička & vodič/vodičica \\
\hline kirurg & kirurgica & kirurg/kirurginja \\
\hline strojovođa & strojovođica & strojovođa/strojovotkinja \\
\hline primarius & primariusa & primarius/primaria \\
\hline jezikoslovac & jezikoslovkinja & jezikoslovac/jezikoslovka \\
\hline revizor & revizorka & revizor/revizorica \\
\hline
\end{tabular}

Iz provedene usporedbe profesijskih naziva koji su metodom masovne podrške uneseni u Rječnik ravnopravnosti i standardnojezičnih naziva može se zaključiti:

\footnotetext{
24 Primjerice na stranici Jezičnoga savjetnika nalaze se ovi jezični savjeti koji se odnose na mocijske parnjake: primalja, diskdžokejica, dadilja, generalica zbora, javna bilježnica, kapetanica korvete, knjigoveškinja, kontraadmiralica, krupije, kućni pomoćnik, mornarica, primalja, roniteljica, poslužiteljica, spasiteljica, striper, taokinja, tekstopiskinja, tkalac, vezilac, vodičica, vršiteljica dužnosti ravnatelja. Svi su savjeti potaknuti korisničkim pitanjima.

25 Standardnojezični nazivi navedeni su prema tražilici mocijskih parnjaka na adresi http://ihjj.hr/musko_ zensko/trazilica/.
} 
1. izvorni govornici imaju problema pri izvođenju nekih mocijskih parnja$\mathrm{ka}^{26}$

2. analizom mocijskih parnjaka može se uočiti stereotipna podjela zanimanja po spolu/rodu, pa onda i profesijskih naziva. Uglavnom je problem pronaći ženski mocijski parnjak, ali za zanimanja kao što je pralja i dadilja problem je kako izvesti muški mocijski parnjak. Tomu se popisu mogu dodati i nazivi hostesa, primalja, medicinska sestra itd. te žargonski naziv teta u vrtiću (službeni je naziv odgojitelj/odgojiteljica), za koji je u Rječniku ravnopravnosti predložen mocijski parnjak tetac u vrtiću.

Tražilica mocijskih parnjaka koja se nalazi na stranicama Muško $i$ žensko u hrvatskome jeziku ${ }^{27}$ stalno se dopunjuje na temelju pitanja korisnika. Preporučeni se mocijski parnjaci utvrđuju korpusnom pretragom, ali i tvorbenom analizom (prema Babić 2002. i odostražnome rječniku mocijskih parnjaka). Na stranici projekta Muško i žensko u hrvatskome jeziku nalazi se i odostražni rječnik mocijskih parnjaka ${ }^{28}$, koji omogućuje da se mocijski parnjaci pretražuju po završetku i da se donesu sustavna rješenja pri uvođenju novih mocijskih parnjaka.

Stereotipna se podjela zanimanja i danas zrcali u nekim oglasima za posao u kojima se iza svakoga profesijskog naziva nalazi oznaka $(m / \check{z})$, ali su unatoč tomu neki nazivi, i to uglavnom oni koji stereotipno označuju žensko zanimanje, navedeni u ženskome rodu, dok je većina naziva u muškome rodu. U Tablici 6 analiziran je jedan tipičan oglas za posao, a mnogo se sličnih primjera može pronaći na internetu jednostavnim pretraživanjem po oznaci $m / \check{z}$.

Tablica 6. Muški i ženski profesijski nazivi u tipičnome oglasu za posao

\begin{tabular}{|l|l|}
\hline muško & žensko \\
\hline voditelj recepcije $(\mathrm{m} / \check{\mathbf{z}})$ & domaćica hotela $(\mathrm{m} / \check{\mathrm{z}})$ \\
\hline recepcioner $(\mathrm{m} / \check{\mathbf{z}})$ & nadzornica soba $(\mathrm{m} / \check{\mathbf{z}})$ \\
\hline pomoćni recepcioner $(\mathrm{m} / \check{\mathbf{z}})$ & sobarica $(\mathrm{m} / \check{\mathbf{z}})$ \\
\hline pomoćni radnik u domaćinstvu $(\mathrm{m} / \check{\mathbf{z}})$ & spremačica/čistačica $(\mathrm{m} / \check{\mathbf{z}})$ \\
\hline skladištar rublja $(\mathrm{m} / \check{\mathrm{z}})$ & \\
\hline voditelj restorana $(\mathrm{m} / \check{\mathbf{z}})$ & \\
\hline glavni konobar $(\mathrm{m} / \check{z})$ & \\
\hline
\end{tabular}

${ }^{26} \mathrm{Na}$ toj se stranici nalazi najviše ženskih mocijskih parnjaka za imenicu znalac: znakinja, znalačica, znalateljica, znalateljka, znalica, znalka, znalkinja, znaltkinja, znalušava, znalja, znankinja.

27 Više o projektu Muško i žensko u hrvatskome jeziku vidi u Mihaljević 2018.

28 O odostražnome rječniku vidi u Lewis i Mihaljević 2018. 


\begin{tabular}{|l|l|}
\hline barmen $(\mathrm{m} / \check{\mathrm{z}})$ & \\
\hline konobar šankist $(\mathrm{m} / \check{\mathrm{z}})$ & \\
\hline pomoćni konobar $(\mathrm{m} / \check{\mathrm{z}})$ & \\
\hline perač posuđa $(\mathrm{m} / \check{\mathrm{z}})$ & \\
\hline voditelj kuhinje $(\mathrm{m} / \check{\mathrm{z}})$ & \\
\hline glavni kuhar $(\mathrm{m} / \check{\mathrm{z}})$ & \\
\hline kuhar $(\mathrm{m} / \check{\mathrm{z}})$ & \\
\hline pomoćni kuhar $(\mathrm{m} / \check{\mathrm{z}})$ & \\
\hline kuhinjski radnik $(\mathrm{m} / \check{\mathbf{z}})$ & \\
\hline radnik na bazenu / redar na plaži $(\mathrm{m} / \check{\mathbf{z}})$ & \\
\hline sportski animator $(\mathrm{m} / \check{z})$ & \\
\hline
\end{tabular}

\subsubsection{Uporaba mocijskih parnjaka}

Uporabu muških i ženskih mocijskih parnjaka u različitim izvorima analizirali su Eugenija Barić (1987, 1989), Stjepan Babić (1999), Barbara Štebih Golub (2014) i Blaženka Martinović (2015). Na probleme do kojih dolazi pri usporednoj uporabi muških i ženskih mocijskih parnjaka upozoravali su Lana Hudeček, Milica Mihaljević i Luka Vukojević (2012) usporedivši istu rečenicu iz Zakona o ravnopravnosti spolova iz 2003. i 2008. godine. U novijoj inačici Zakona neki su previdi ispravljeni, ali su drugi još ostali, što je pokazano u Tablici 7 (sporni su dijelovi podcrtani).

Tablica 7. Usporedba iste rečenice iz Zakona o ravnopravnosti spolova iz 2003. i 2008. godine

\begin{tabular}{|l|l|}
\hline Zakon o ravnopravnosti spolova iz 2003. & Zakon o ravnopravnosti spolova iz 2008. \\
\hline Za pravobranitelja/icu i njegovog/njezinog & Za pravobranitelja/icu i njegovog/njezinog \\
zamjenika/icu može biti imenovan hrvatski & zamjenika/icu može biti imenovan hrvatski \\
državljanin/ka koji ima visoku stručnu spremu & državljanin/ka koji ima završen diplomski \\
i koji je osobnim zalaganjem poznat javnosti u u & $\begin{array}{l}\text { sveučilišni studij i koji/a je osobnim zala- } \\
\text { području zaštite ljudskih prava. }\end{array}$ \\
& $\begin{array}{l}\text { ganjem poznat/a javnosti u području zaštite } \\
\text { ljudskih prava. }\end{array}$ \\
\hline
\end{tabular}

Da analizirana rečenica nije izdvojen slučaj, pokazuje i ova rečenica iz istoga Zakona (2008.):

Pravobranitelj/ica i njegov/njezin zamjenik/ica bit će razriješeni dužnosti prije isteka mandata na koji su imenovani... Iako u tekstu koji je samo malo dulji od jednoga retka ima tri dvostruka oblika, to još uvijek nije dovoljno. Ako su duž- 
nosti razriješene pravobraniteljica i njezina zamjenica, rečenica bi trebala glasiti ovako: Pravobraniteljica i njezina zamjenica bit će razriješene dužnosti prije isteka mandata na koji su imenovane, pa bi početna rečenica trebala glasiti Pravobranitelj/ica i njegov/njezin/njegova/njezina zamjenik/ica bit će razriješeni/e dužnosti prije isteka mandata na koji su imenovanile...

Zanimljiv je i primjer zabilježen s mrežnih stranica jedne udruge: Skupština udruge donosi Statut... imenuje i razrješava Predsjednika Udruge, Zamjenikal cu Predsjednika udruge i Dopredsjednike udruge. Tako oblikovana rečenica upućuje na to da se pretpostavlja da bi samo dužnost zamjenika mogla obnašati i žena.

Za razliku od gornjih primjera u nedavno objavljenome proglasu Inicijative s Filozofskoga fakulteta u Zagrebu o zaštiti žrtava seksualnoga nasilja na prvome se mjestu navodi ženski mocijski parnjak, a na drugome muški mocijski parnjak. To je vjerojatno uvjetovano uobičajenim pravilom pristojnoga ophođenja po kojemu se ženski mocijski parnjak navodi na prvome mjestu (npr. kolegice $i$ kolege, a ne kolege $i$ kolegice), ali budući da su ženski mocijski parnjaci najčešće izvedeni od muških mocijskih parnjaka dodavanjem sufiksa, takav način pisanja dovodi do još nerazumljivijega teksta od onoga u gornjim primjerima, npr. Seksualno nasilje i uznemiravanje na fakultetima, desetljećima zanemarivan i prešućivan problem, našao se u fokusu javnosti zbog mnogobrojnih studenticala diljem regije, a među njima i kolegicala s našeg Fakulteta, koje/i su hrabro odlučile/i prijaviti svoja iskustva spolnog, rodnog i seksualnog nasilja i uznemiravanja koja su doživjele/i tijekom svoga studija. Ako se već htjelo navesti i muške i ženske mocijske parnjake te staviti ženski mocijski parnjak na prvo mjesto, svakako bi bilo bolje i razumljivije da je ispisan svaki mocijski parnjak u cijelosti, a ne padežni nastavak za koji je posve nejasno na što se dodaje. Dodatno se postavlja pitanje kako bi se postupilo u slučaju uporabe nominativa jednine, npr. studentica/Ø. Usto ni to nije provedeno dosljedno u čitavome tekstu, pa u njemu nalazimo samo profesori, pravni stručnjaci i stručnjaci (ne i profesorice, pravne stručnjakinje i stručnjakinje) te zlostavljača/zlostavljačica ${ }^{29}$. U posljednjemu je primjeru prekršen i redoslijed i načelo navođenja samo nastavaka, prema tome kako je pisan ostatak teksta, trebalo bi biti zlostavljačica/a.

29 Ovdje je zamijenjen redoslijed valjda zbog stereotipne predodžbe da je muškarac zlostavljač. 
Posebno je zanimljivo analizirati uporabu muških i ženskih mocijskih parnjaka pri obraćanju mješovitomu slušateljstvu, npr. poštovane ravnateljice i ravnatelji, pročelnici teorijskih odjela, drage kolegice i kolege, dragi članovi društva. Pri analizi duljih obraćanja (pretraživanjem korpusa s pomoću riječi poštovan, drag itd.) utvrđeno je da se pri duljim obraćanjima redovito izostavljaju pridjevi u muškome rodu i ženski mocijski parnjaci s odgovarajućim pridjevima. Gornja bi rečenica, kad bi se dosljedno provelo pravilo dvostruke uporabe mocijskih parnjaka i njima pridruženih kategorija, trebala glasiti poštovane ravnateljice $\underline{i}$ poštovani ravnatelji, pročelnice $i$ pročelnici teorijskih odjela, drage kolegice $i$ dragi kolege, drage članice i dragi članovi društva...

Navedeni primjeri pokazuju da je u hrvatskome jeziku gotovo nemoguće dosljedno provesti usporednu uporabu muških i ženskih mocijskih parnjaka te da se time dobiva tekst koji je iznimno nerazumljiv i dugačak. Posebno je nepregledno ako su navedeni samo nastavci, i to posebno ako je prvo naveden ženski mocijski parnjak. Također množina ne rješava problem uporabe osobnih zamjenica kao u engleskome, a ni uporabe pridjeva i glagolskih oblika.

Katkad se susreću i drugi primjeri i prijedlozi da bi se postigla spolna/rodna neutralnost:

1. U tekstu u kojemu se govori o mentorima i volonterima u množini će se upotrebljavati ti nazivi a u jednini samo donja crta (_) jer se odnosi $i$ na muški i na ženski rod. Donjom se crticom izražava slobodan prostor između dvaju rodova i stoga je prikladnija od kose crte koja označuje razdvajanje / (mišljenje o ovome postupku traženo je od jezičnoga savjetnika).

2. U knjizi Činjenice i vrijednosti (Polić 2006: 230) spominje se prijedlog da se umjesto bio sam ili bila sam upotrijebi neobilježeni oblik bijah.

\section{Prema spolno/rodno nediskriminirajućoj e-leksikografiji}

Stereotipni pristup muško-ženskim odnosima odražava se i u leksikografskoj obradi muških i ženskih mocijskih parnjaka u hrvatskim rječnicima u prošlosti i danas. O mocijskim odnosima u odabranim hrvatskim gramatikama i rječnicima do objavljivanja Parčićeva rječnika 1901. godine pisale su Marijana Hor- 
vat i Milica Mihaljević (2019). O mocijskim parnjacima u suvremenim rječnicima pisale su Maja Bratanić (2005), Milica Mihaljević i Barbara Štebih Golub (2009), Milica Mihaljević (2013), Blaženka Martinović (2015), a o profesijskim nazivima u hrvatskoj e-leksikografiji i e-terminolografiji Lana Hudeček i Milica Mihaljević (2019). U ovome radu tomu se problemu pristupa sa stajališta spolne/ rodne ravnopravnosti na primjeru Mrežnika i Jene.

Za ovu su temu bitne dvije razlike između e-rječnika i terminoloških baza podataka s jedne strane i klasičnih općih i terminoloških rječnika s druge strane: 1. e-rječnici i baze podataka temelje se na računalnome korpusu i 2. u e-rječnicima i bazama podataka nema prostornoga ograničenja.

\subsection{Primjer Mrežnika $a^{30}$}

Mrežnik je jednojezični korpusno utemeljen rječnik koji ima tri modula (opći, školski i modul namijenjen neizvornim govornicima) i koji će po završetku projekta biti javno dostupan na internetu na adresi rjecnik.hr. U Mrežniku su ova polja povezana s navedenom temom, pa će stoga biti analizirana u ovome radu: 1. natuknica, 2. definicija, 3. primjeri i kolokacije, 4. napomena.

\subsubsection{Natuknica}

U skladu s načelom spolne/rodne uključivosti i nediskriminacije u Mrežniku se dosljedno navode muški i ženski mocijski parnjaci i njihovi posvojni pridjevi. ${ }^{31}$ Obrađuju se u posebnoj natuknici bez obzira na njihovu zastupljenost u korpusu. Primjerice riječ vatrogasac u $h r W a C-u$ potvrđena je 68453 puta, a riječ vatrogaskinja samo 134 puta. Pridjev vatrogaščev ima 10 potvrda, a pridjev vatrogaskinjin nema ni jednu potvrdu. Ipak, obje su imenice i oba pridjeva ravnopravno obrađeni u Mrežniku, kao što je prikazano u Tablici 8.

\footnotetext{
30 O projektu Mrežnik vidi Hudeček i Mihaljević 2017a, 2017b i 2020 b.

31 To se naravno ne odnosi na mocijske parove u kojima iz izvanjezičnih razloga ne postoji jedan parnjak, vidi Lewis 2014.
} 
Tablica 8. Obrada natuknica vatrogasac, vatrogaskinja, vatrogaščev i vatrogaskinjin

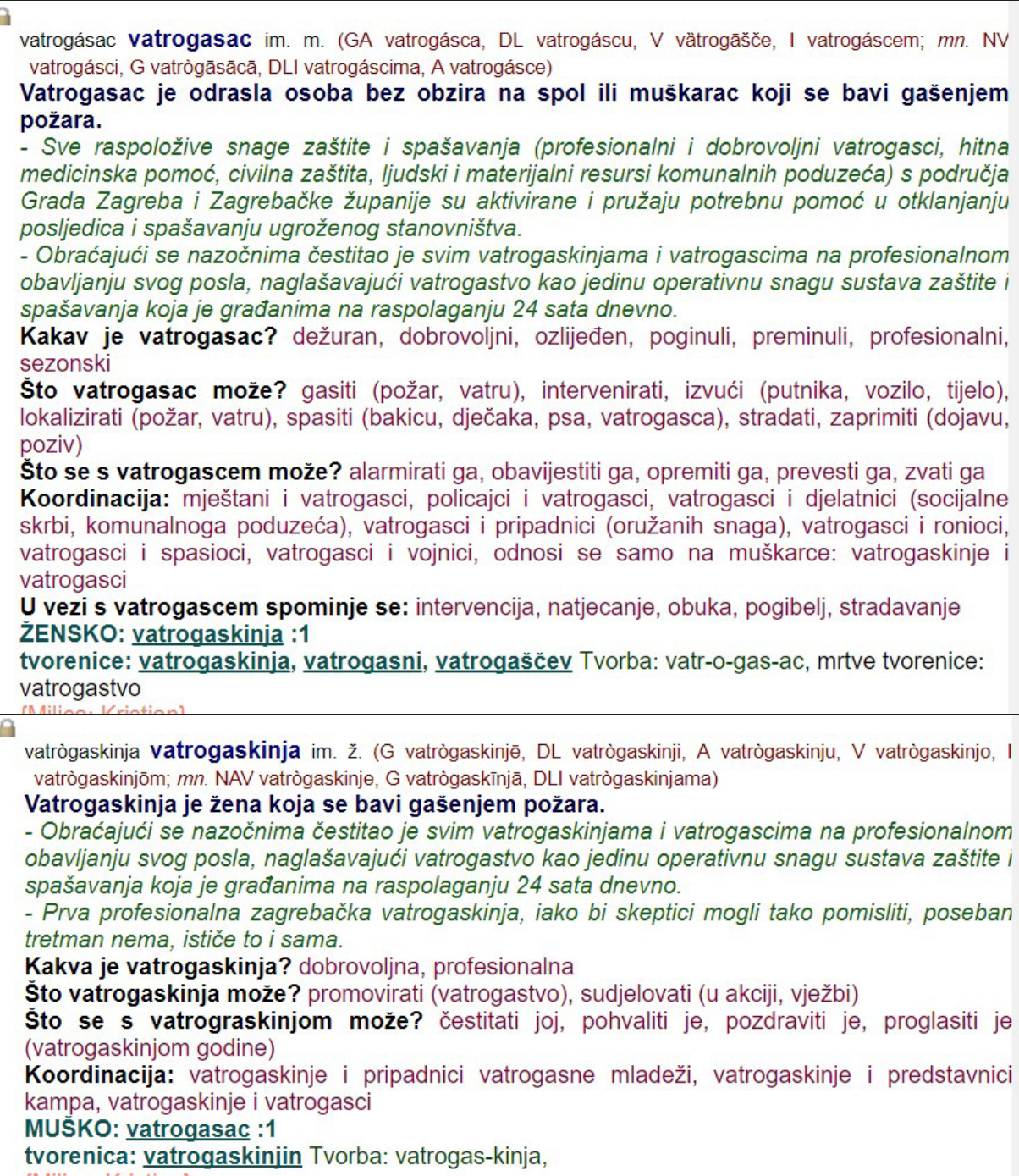




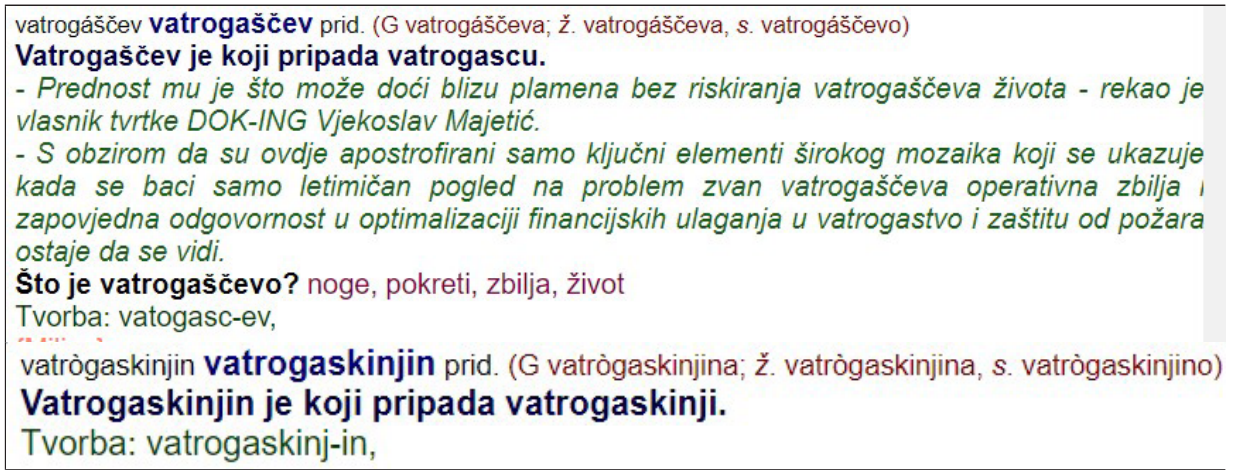

\subsubsection{Definicija}

Muški mocijski parnjak uvijek ima dva značenja: 1. osoba, 2. muškarac. Na to upozorava i Blaženka Martinović u radu Od jezičnoga ,pomuškarčivanja” do jezičnoga ,poženčivanja” (2015: 102). Pri razvijanju modela obrade u Mrežniku krenulo se od ideje da se navedena značenja razdvoje, ali je to dovelo do toga da se u višeznačnim natuknicama (npr. učitelj, profesor, nastavnik) ${ }^{32}$ udvostručuje obrada i dobiva izrazito nepregledan rječnički članak s mnogo ponavljanja. Stoga je zaključeno da uz muški mocijski parnjak definicija glasi odrasla osoba bez obzira na spol ili muškarac (vidi definiciju imenice vatrogasac u Tablici 8) ili osoba bez obzira na spol ili muška osoba (kad se može primijeniti i na djecu i dječake).

\subsubsection{Primjeri i kolokacije}

Mrežnik je korpusno utemeljen e-rječnik. Iz korpusa se često iščitavaju jezični stereotipi čije bi unošenje u rječnik (u primjerima ili kolokacijama) dovelo do neprimjerenoga opisa. U radu Mihaljević (2018: 215) analiziraju se rezultati korpusne pretrage natuknica muškarac i žena i mladić i djevojka u hrWaC-u te se između ostaloga utvrđuje da se pridjevi lijep, mlad i bivši mnogo češće pojavljuju uz lemu djevojka nego uz lemu mladić, da se uz imenicu žena najčešće nalaze pridjevi mlada, lijepa, udana, nesretna, zgodna, trudna, nezaposlena,

32 Vidi Mihaljević 2018: 221-224. 
pametna, zlostavljana, silovana, zaposlena, a uz lemu muškarac nepoznat, oženjen, odrastao, naoružan, maskiran, zgodan, sredovječan, privlačan, mlad, pravi, heteroseksualan. U radu Hudeček i Mihaljević (2018) spominju se primjeri prsata konobarica, sisata konobarica i brkata konobarica ${ }^{33}$ te pohotna pekarica (2018: 106) kao rezultati dobiveni iz korpusa koji sigurno svoje mjesto ne bi trebali dobiti u mrežnome rječniku. Razlikovna skica riječi konobar i konobarica prikazana je na Slici 2.

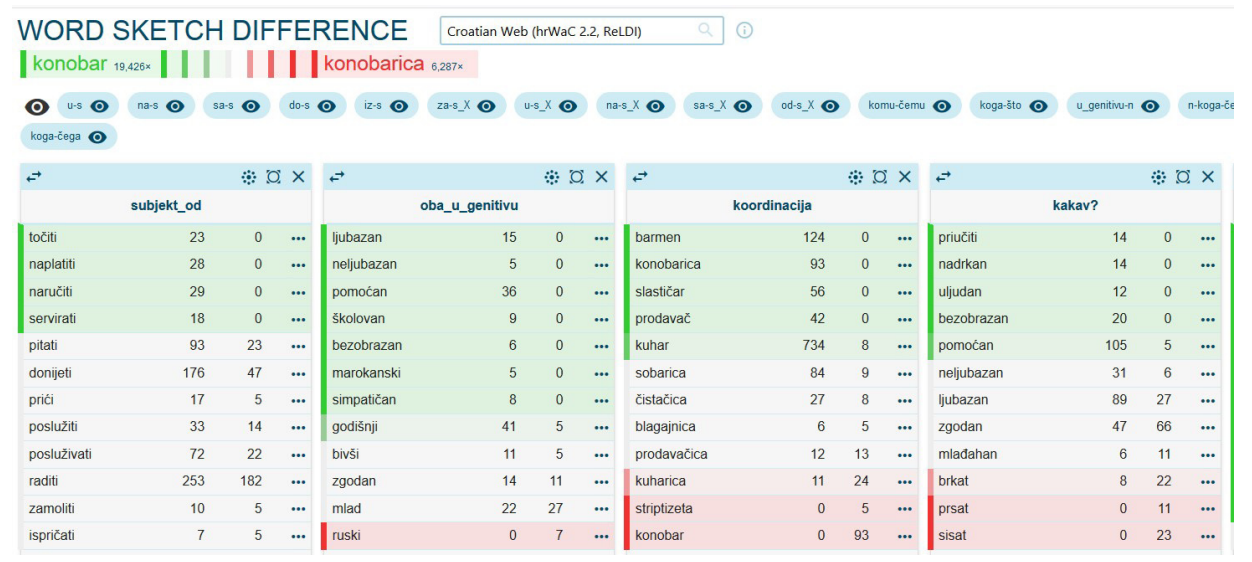

Slika 2. Razlikovna skica riječi konobar i konobarica

Dok je konobar priučen, nadrkan, uljudan, bezobrazan i pomoćni, konobarica je brkata, prsata i sisata. Konobar se koordinacijski povezuje s barmenom, slastičarom, prodavačem i kuharom, a konobarica s kuharicom, ali i striptizetom.

Na Slici 3 prikazane su razlikovne skice riječi sobar i sobarica. Dok je sobar između ostaloga uhićen, osuđen i pomilovan, sobarica je prelijepa, seksi, francuska i naivna.

\footnotetext{
33 Brkata se konobarica spominje u pjesmi glazbenoga sastava Hladno pivo, pa je zbog toga među najčešćim kolokacijama riječi konobarica.
} 
| sobar ${ }_{472 x}$ | || | | || | | | sobarica $2.222 x$ $2 \pm 0$ :

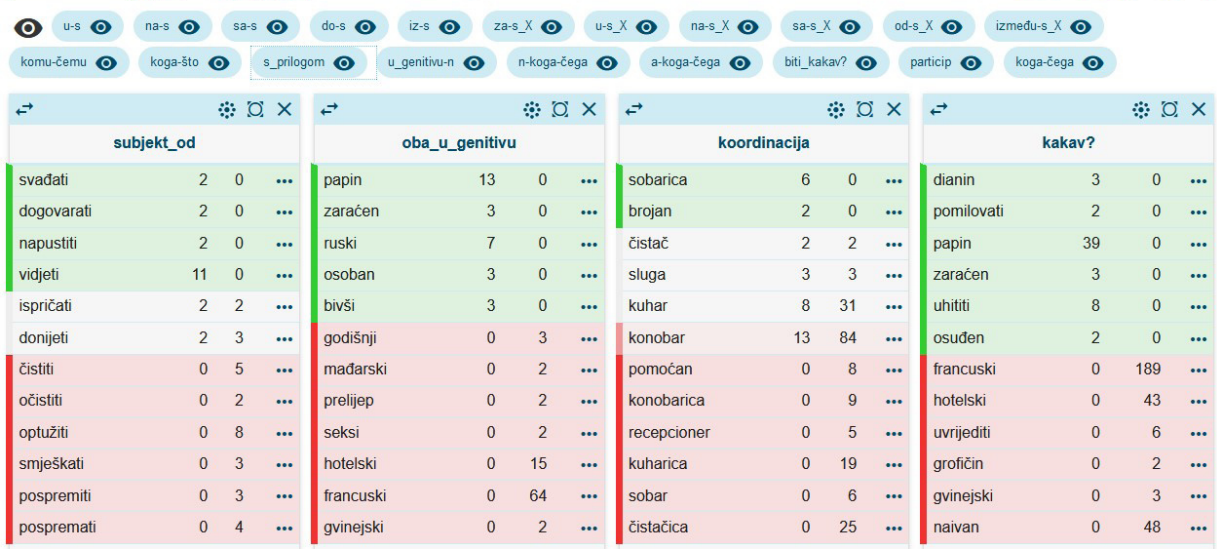

Slika 3. Razlikovna skica riječi konobar i konobarica

Na Slici 4 prikazane su razlikovne skice riječi tajnik i tajnica.

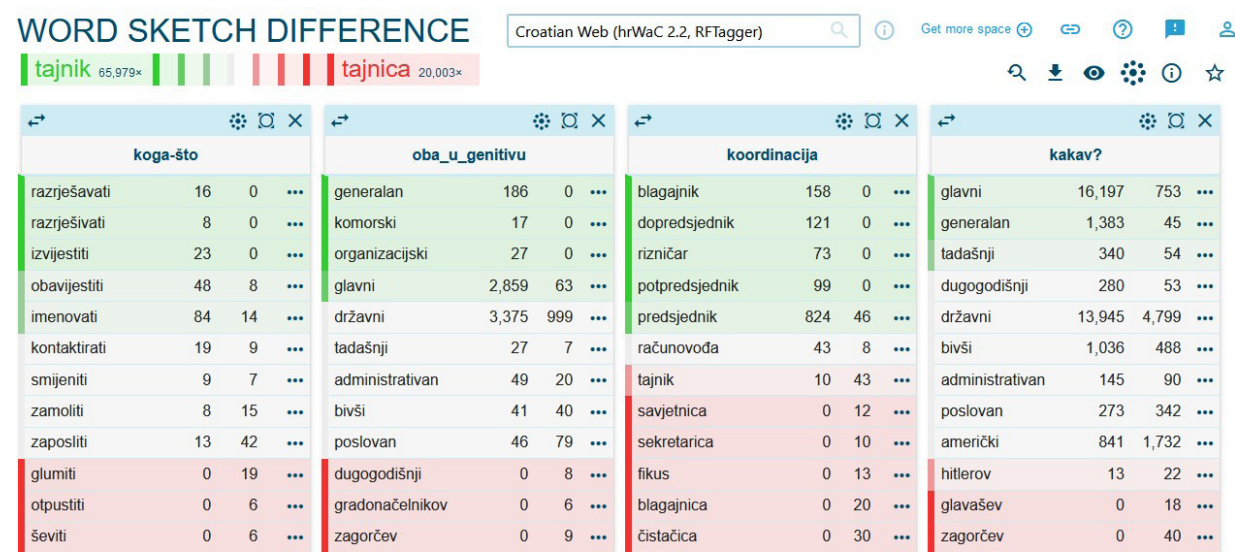

\section{Slika 4. Razlikovna skica riječi tajnik i tajnica}

Skice riječi pokazuju da je tajnik glavni, generalni i tadašnji, dok je tajnica Hitlerova, Glavaševa i Zagorčeva (dakle, određena pripadnošću svojemu šefu). Dok tajnika možemo razrješavati, izvijestiti, obavijestiti i imenovati, tajnicu možemo otpustiti, ali i ševiti. 
Pri obradi natuknica u Mrežniku nisu se donosili uvredljivi primjeri i kolokacije bez obzira na njihovu zastupljenost u korpusu te su u najvećoj mjeri izbjegavani stereotipi.

\subsubsection{Jezični savjet}

Jedna je od značajka Mrežnika kao normativnoga rječnika da se u njemu donose jezični savjeti i normativne napomene u svim trima modulima. Uz sve se mocijske parnjake u Mrežniku u dječjemu modulu donosi jezični savjet u kojemu se primjereno dječjoj dobi objašnjava kad se upotrebljava muški, a kad ženski mocijski parnjak. Na Slici 5 prikazan je jezični savjet u kojemu se objašnjava uporaba mocijskih parnjaka vatrogasac i vatrogaskinja.

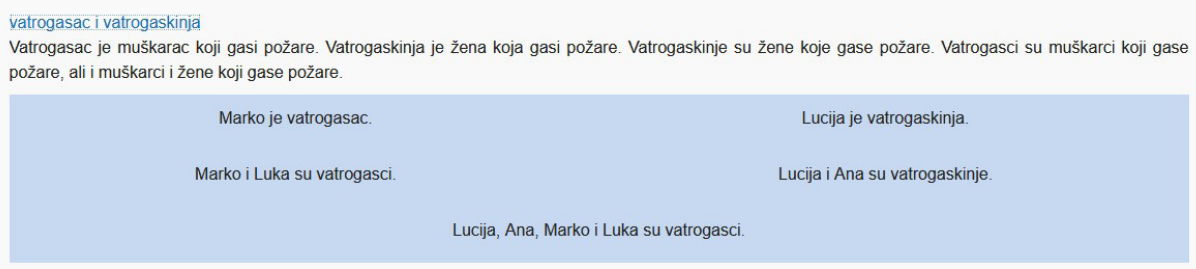

Slika 5. Jezični savjet uz natuknice vatrogasac i vatrogaskinja

\subsection{Primjer Jene}

Jena je terminološka baza jezikoslovnoga nazivlja koja se izrađuje u okviru projekta Struna. Za Jenu je problem spolne/rodne ravnopravnosti i uključivosti jezika relevantan iz dvaju razloga: 1. u Jenu se unosi nazivlje spolne/rodne (ne) diskriminacije, 2. u Jenu se unose i muški i ženski mocijskih parnjaci za sve profesijske nazive koji pripadaju jezikoslovlju.

\subsubsection{Natuknica}

U Jeni se dosljedno donose mocijski parnjaci profesijskih naziva ${ }^{34}$ iako se neki rijetko ili nikad ne pojavljuju u korpusu. U Tablici 9 prikazana je pojava pojedinih mocijskih parnjaka u Jezikoslovnome korpusu.

34 Vidi Hudeček i Mihaljević 2019. 
Tablica 9. Mocijski parnjaci u Jezikoslovnome korpusu

\begin{tabular}{|l|l|l|l|}
\hline muški mocijski parnjak & broj pojavnica & ženski mocijski parnjak & broj pojavnica \\
\hline antroponomastičar & 4 & antroponomastičarka & 2 \\
\hline jezikoslovac & 970 & jezikoslovka & 26 \\
\hline kroatist & 116 & kroatistica & 11 \\
\hline leksikograf & 342 & leksikografkinja & 3 \\
\hline lingvist & 733 & lingvistica & 10 \\
\hline onomastičar & 136 & onomastičarka & 0 \\
\hline prevoditelj & 567 & prevoditeljica & 23 \\
\hline
\end{tabular}

\subsubsection{Definicija}

U Jeni se uz profesijski naziv u muškome rodu navodi tipska definicija koja počinje riječima osoba koja..., što je vidljivo na Slici 6 na primjeru natuknice jezikoslovac.

jezikoslovac

status naziva: naziv || obrađivač: Milica Mihaljević || faza obradbe: zaključano || autorski: ne

definicija: osoba koja je završila diplomski ili doktorski studij kojega jezikoslovnog smjera i profesionalno se bavi proučavanjem jezika

radna definicija: osoba koja je završila diplomski ili doktorski studij kojega jezikoslovnog smjera i profesionalno se bavi proučavanjem jezika

projekt: jezikoslovlje

potpodručje: temeljno jezikoslovno nazivje

istovrijednica - engleski: linguist
istovrijednica - njemački: Sprachwissenschaftler, Linguist
istovrijednica - francuski: linguiste
istovrijednica - ruski: пингвист; языковед
istovrijednica - švedski: språłvetare; lingvist
jezična odrednica: imenica
broj: jednina
rod: muški
poveznica: https://hrcak.srce.hr/index.php?show=clanak\&id_clanak_jezik=329420

napomena: Nazivi jezikoslovac i lingvist u općemu značenju i u množini mogu se odnositi i na mušku i na żensku osobu. Uz ime ženske osobe navodi se naziv jezikoslovka ili lingvistica.

Slika 6. Natuknica jezikoslovac u Jeni

\subsubsection{Napomena}

Uz sve se profesijske nazive u Jeni nalazi i tipska napomena u kojoj je objašnjeno kad treba upotrijebiti muški, a kad ženski mocijski parnjak. To je vidljivo u natuknici jezikoslovac na Slici 5. 


\section{Zaključak}

Jezik je jedno od najmoćnijih sredstava s pomoću kojega se očituje i reproducira seksizam i spolna/rodna diskriminacija. Stoga treba težiti stvaranju jezičnoga izričaja koji uklanja stereotipe i predrasude. Međutim, strategije izgradnje jezika ravnopravnosti razlikuju se od jezika do jezika i nemoguće je reproducirati gotove strane obrasce u hrvatskome, a da se ne dobije posve nerazumljiv i neprirodan tekst, što je pokazano na korpusnim primjerima. Za jezik spolne/rodne ravnopravnosti važno je izgraditi izbalansiran sustav mocijskih parnjaka bez praznih mjesta u sustavu. Pritom treba voditi računa o tome da i izvorni govornici često imaju problema sa stvaranjem i uporabom mocijskih parnjaka. Mocijski parnjaci muškoga roda imaju dva značenja: 1. muškarac, 2. osoba. Mocijski parnjaci ženskoga roda označuju ženu i treba ih uvijek upotrebljavati kad se govori o konkretnoj ženi, npr. na posjetnici, u poslovnome pismu, na mrežnim stranicama, u životopisu. Za sve profesijske nazive zbog spolne/rodne ravnopravnosti nužno je imati i muški i ženski mocijski parnjak, ali se oni ne trebaju upotrebljavati usporedno u svim slučajevima jer to dovodi do nejasnih i predugih tekstova. Stvaranje rječnika i baza podataka društveno je odgovorna djelatnost i u njima se ne bi trebali reproducirati stereotipi i predrasude, čak ni oni koji su prisutni u korpusima, nego bi i oni trebali biti usmjereni stvaranju jezika bez spolne/rodne diskriminacije. To se posebno može postići tako da su ženski i muški mocijski parnjaci posebne, $u$ potpunosti obrađene i ravnopravne natuknice, da se u definiciji jasno odredi da se muški mocijski parnjak odnosi na osobe bez obzira na spol, tj. ravnopravno se odnosi i na žene i na muškarce, da se ženski mocijski parnjak nikad ne definira s pomoću muškoga, što je u leksikografiji često bila praksa, da se navode nediskriminirajući primjeri i kolokacije, da se daju jezični savjeti i primjeri koji upućuju na to kad i kako upotrijebiti koji mocijski parnjak. Usto u jezikoslovnu terminološku bazu podataka treba unijeti i nazivlje povezano sa spolnom/rodnom neutralnošću i (ne)jednakošću u jeziku. Zbog toga su u ovome radu analizirani i neki temeljni nazivi spolne/rodne (ne)ravnopravnosti, a budući da se to nazivlje brzo razvija, treba ga redovito dopunjavati i dograđivati. 


\section{Mrežni izvori}

editage Insights. https://www.editage.com/insights/should-i-use-the-word-sex-or-gender-in-my-scientific-research-paper (pristupljeno 11. veljače 2021.).

Englesko-hrvatski rječnik, Glosbe. https://hr.glosbe.com/en/hr (pristupljeno 21. veljače 2021.).

Gender Equality Law Center. https://www.genderequalitylaw.org/gender-stereotyping (pristupljeno 11. veljače 2021.).

Gender-neutral language in the European Parliement. 2018. http://www.europarl.europa.eu/cmsdata/151780/GNL_Guidelines_EN.pdf) (pristupljeno prosinac 2020. - veljača 2021.).

Gender-sensitive Communication. https:/eige.europa.eu/publications/gender-sensitive-communication/first-steps-towards-more-inclusive-language/terms-you-need-know (pristupljeno 28. veljače 2021.).

Guidelines for Nonsexist Language in APA Journals. 1978. Educational Researcher. http://www.jstor.org/stable/1175970 (pristupljeno 28. veljače 2021.).

Hrvatsko strukovno nazivlje - Struna. http://struna.ihjj.hr/ (pristupljeno prosinac 2020.).

Jezični savjetnik. http://jezicni-savjetnik.hr/ (pristupljeno prosinac 2020.).

Muško i žensko u hrvatskome jeziku. http://ihjj.hr/musko_zensko/ (pristupljeno prosinac 2020.).

Pojmovnik rodne terminologije https://ravnopravnost.gov.hr/UserDocsImages/arhiva/ preuzimanje/biblioteka-ona/Publikacija_Pojmovnik\%20rodne\%20terminologije $\% 20$ prema $\% 20$ standardima\%20Europske\%20unije.pdf (pristupljeno prosinac 2020. - veljača 2021.).

Portrayal Guidelines for Gender Balanced Representation. https://stillmedab.olympic. org/media/Document\%20Library/OlympicOrg/IOC/What-We-Do/Promote-Olym-

pism/Women-And-Sport/Guide-Genders-Balanced-Representation.pdf （pristupljeno prosinac 2020. - veljača 2021.).

United Nations Human Rights. https:/www.ohchr.org/en/issues/women/wrgs/pages/ genderstereotypes.aspx (pristupljeno prosinac 2020. - veljača 2021.).

Wikipedia. Genderless language. https://en.wikipedia.org/wiki/Genderless_language (pristupljeno prosinac 2020. - veljača 2021.).

Zakon o ravnopravnosti spolova. https://narodne-novine.nn.hr/clanci/sluzbeni/2008_07_82_2663.html (pristupljeno prosinac 2020. - veljača 2021.).

Ženska soba. Jezik ravnopravnosti. http://zenskasoba.hr/hr/jezik-ravnopravnosti/ (pristupljeno prosinac 2020. - veljača 2021.). 


\section{Literatura}

BABIć, StJEPAn. 1999. Ženska zanimanja u Hrvatskome bibliografskome leksikonu. Jezik 46/5. 191-193.

Babić, StJePan. 2002. Tvorba riječi u hrvatskome književnome jeziku. Nakladni zavod Globus, Hrvatska akademija znanosti i umjetnosti. Zagreb.

BARIĆ, EugEnIJA. 1987. Mocijski parnjaci i njihova upotreba. Rasprave Zavoda za jezik 13. 9-18.

BARIĆ, EugENIJA. 1989. Ženski mocijski parnjak kao funkcionalna komunikacijska kategorija. Jezik 37/1. 12-21.

BIRTIĆ, MATEA I DR. 2012. Školski rječnik hrvatskoga jezika. Institut za hrvatski jezik i jezikoslovlje - Školska knjiga. Zagreb.

Bratanić, Maja. 2005. Mjesto žene u rječniku. Jezik u društvenoj interakciji. Ur. Stolac, Diana; Ivanetić, Nada; Pritchard, Boris. Hrvatsko društvo za primijenjenu lingvistiku. Zagreb - Rijeka. 37-46.

Heffer, Hrvoja. 2007. Biološka i društvena kategorija roda u rodnoj teoriji i rodna teorija stereotipa. Rasprave: Časopis Instituta za hrvatski jezik i jezikoslovlje 33/1. $165-175$.

Horvat, Marijana; Mihaljević, Milica. 2019. Dijakronijski pogled na mocijske imenice. Rasprave: Časopis Instituta za hrvatski jezik i jezikoslovlje 45/1. 27-45. doi. org/10.31724/rihjj.45.1.2.

HudeČeK, Lana; Minaljević, Milica. 2012. Hrvatski terminološki priručnik. Institut za hrvatski jezik i jezikoslovlje. Zagreb.

Hudeček, Lana; MiHaljević, Milica. 2017a. Hrvatski mrežni rječnik - Mrežnik. Hrvatski jezik 4/4. 1-8.

Hudeček, Lana; Minaljević, Milica. 2017b. The Croatian Web Dictionary Project Mrežnik. Electronic lexicography in the 21st century. Proceedings of eLex 2017 conference. Ur. Kosem, Iztok i dr. Lexical Computing CZ s.r.o. Brno - Leiden. 172-192.

Hudeček, Lana; Mihaluević, Milica. 2018. Croatian Web Dictionary Mrežnik: One year later - What is different? Proceedings of the Conference on Language Technologies \& Digital Humanities. Ur. Fišer, Darja; Pančur, Andrej. Ljubljana. 106-113.

Hudeček, LanA; Mihaljević, Milica. 2018. Hrvatski mrežni rječnik - Mrežnik: Upute za obrađivače. http://ihjj.hr/mreznik/uploads/upute.pdf.

Hudeček, Lana; Mihaljević, Milica. 2019. Profesijski nazivi u hrvatskoj e-terminografiji i e-leksikografiji. Studia lexicographica 13/24. 75-95. doi.org/10.33604/ sl.13.24.2. 
Hudeček, Lana; Mihaljević, Milica. 2020a. Hrvatsko jezikoslovno nazivlje - Jena. Hrvatski jezik 7/4. 1-7.

Hudeček, Lana; Mihaljević, Milica. 2020b. The Croatian Web Dictionary - Mrežnik Project - Goals And Achievements. Rasprave: Časopis Instituta za hrvatski jezik $i$ jezikoslovlje 46/2. 645-667. doi.org/10.31724/rihjj.46.2.11.

Hudečex, Lana; Mihaljević, Milica; Jozić, ŽEluko (ur.). 2020. Hrvatsko jezikoslovno nazivlje. Institut za hrvatski jezik i jezikoslovlje. Zagreb.

Hudečex, Lana; Mihaljević, Milica; Vukojević, Luka. 2012. Jezični savjeti. Institut za hrvatski jezik i jezikoslovlje. Zagreb.

Kilgarriff, Adam; Rychlý, Pavel; Smrz, Pavel; Tugwell, David. 2004. The Sketch Engine. Proceedings of the 11th EURALEX International Congress. Ur. Williams, G.; Vessier, S. Universite de Bretagne - sud. Lorient. 105-116.

Kovačević, Barbara. 2019. Muško i žensko u frazeologiji I . Hrvatski jezik 6/4: 26-29.

KovaČEviĆ, BARBARA. 2020. Muško i žensko u frazeologiji II. Hrvatski jezik 7/1: 2326.

Lewis, Kristian. 2014. Parnjaci kojima nema para. Hrvatski jezik 1/4. 8-11.

Lewis, KRistian; MihalJević, Josip. 2018. Odostražni rječnik - što je, kako ga izraditi i čemu služi. Hrvatski jezik 5/2. 21-25.

Marković, Mario; Mihaljević, Josip. 2020. Korpus Jene - jednojezični terminološki korpus. Hrvatsko jezikoslovno nazivlje - JENA. Ur. Mihaljević, Milica; Hudeček, Lana; Jozić, Željko. Institut za hrvatski jezik i jezikoslovlje. Zagreb. 110-123.

Marković, Mario; Mihaljević, Josip; Mihaljević, Milica. 2020. Kako pronaći jezikoslovni naziv. Hrvatski jezik 7/1. 18-22.

Martinović, BlažEnKa. 2015. Od jezičnoga ,pomuškarčivanja” do jezičnoga „poženčivanja”. Tabula 13/1. 91-110. doi.org/10.32728/tab.13.1.2015.05.

Menegatti, Michaela; Rubini, Monica. 2017. Gender Bias and Sexism in Language. Oxford Research Encyclopedia of Communication. doi.org/10.1093/ acrefore/9780190228613.013.470.

Minaljević, Milica. 2013. Mocijska tvorba kao leksikografski problem. Od indoeuropeistike do kroatistike. Zbornik u čast Daliboru Brozoviću. Ur. Matasović, Ranko. HAZU. Zagreb.

Mihaljević, Milica, HudeČEK, Lana; Jozić, ŽEluko (ur.). 2020. Hrvatsko jezikoslovno nazivlje. Institut za hrvatski jezik i jezikoslovlje. Zagreb.

Mihaljević, Milica. 2018. Muško i žensko u e-rječniku. Zbornik radova s međunarodnoga znanstvenog skupa Hrvatskoga društva za primijenjenu lingvistiku održanoga od 4. do 6. svibnja 2017. Jezik i njegovi učinci. Ur. Stolac, Diana; Vlastelić, Anastazija. Srednja Europa. Zagreb. 209-228. 
Mihaljević, Milica; Štebih Golub, Barbara. 2009. Mocijska tvorba u hrvatskome i srpskome jeziku. Die Unterschiede zwischen dem Bosnischen/Bosniakischen, Kroatischen und Serbischen III. Slawische Sprachkorelationen. Ur. Tošović, Branko. Wien. 81-103.

Miloš, Irena. 2014. Jezik i identitet. Što nam o tome govore baba i deda? Hrvatski jezik 1/1. 12-13.

Miloš, Irena. 2017. Komu je jezik majka, a komu maćeha? Hrvatski jezik 4/4. 8-10.

Nahod, Bruno. 2020. Terminološka baza Struna. Hrvatsko jezikoslovno nazivlje JENA. Ur. Mihaljević, Milica; Hudeček, Lana; Jozić, Željko. Institut za hrvatski jezik i jezikoslovlje. Zagreb. 1-7.

OMrČEn, DARIJA. 2017. Analysis of gender-fair language in sport and exercise. Rasprave: Časopis Instituta za hrvatski jezik i jezikoslovlje 43/1. 143-161.

PIŠKović, TATJAna (ur.) 2018. Uvod u rodolektologiju. Rodni jezici. Zbornik radova o jeziku, rodu i spolu. Filozofski fakultet Sveučilišta u Zagrebu. Zagreb.

PIŠKović, TATJAna. 2014. Feministički otpor rodnoj asimetriji u jeziku i jezikoslovlju. Otpor. Subverzivne prakse u hrvatskom jeziku, književnosti i kulturi. Zbornik radova 42. seminara Zagrebačke slavističke škole. Ur. Pišković, Tatjana; Vuković, Tvrtko. FF press. Zagreb. 145-168.

Polić, Milan. 2006. Činjenice i vrijednosti. Hrvatsko filološko društvo. Zagreb.

Sczesny, Sabine, Moser, Franziska; Wood, Wendy. 2015. Beyond Sexist Beliefs: How Do People Decide to Use Gender-Inclusive Language? Personality and Social Psychology Bulletin. 943-954. doi.org/10.1177/0146167215585727.

Sczesny, Sabine; Formanowicz, Magda; Moser, Franziska. 2016. Can gender-fair language reduce gender stereotyping and discrimination? Frontiers in Psychology 7. doi.org/10.3389/fpsyg.2016.00025.

Štebih Golub, Barbara. 2014. O mociji bez emocija. Srpski jezik 19. 461-478.

Vilinbakhova, Elena. 2014. Stereotype in linguistics: history of the study. Language and language behavior 14. 230-236.

\section{Male and Female in Croatian Language and Lexicography - Stereotypes and Language Discrimination}

\section{Abstract}

Language is one of the most powerful means through which sexism and gender discrimination are perpetrated and reproduced. Language subtly reproduces the societal asymmetries of status and power in favor of men, which are attached to the corresponding social roles (Menegatti and Rubini 2017). Gender stereotypes are reproduced in the 
language and mirrored in lexicographic works. Gender-fair language aims at reducing gender stereotyping and discrimination (Sczesny, Formanowicz and Moser 2016). The principle of gender equality and non-discrimination on gender grounds is firmly rooted in the legislation of the European Union (Gender-neutral Language in the European Parliament). However, the principles of gender neutrality in language require the use of different strategies in different languages depending on different language systems. English is a natural gender language in which personal nouns are mostly gender-neutral. Croatian on the other hand is a grammatical gender language in which all nouns are gender-specific as are personal and possessive pronouns, adjectives, and some verbal forms. Thus, it is impossible to use English gender-neutral strategies in Croatian. In the paper, the author analyzes the approach to Croatian feminine and masculine professional nouns and problems of Croatian word-formation connected with stereotypes and their implications for e-lexicography on the example of Jena and Mrežnik.

Ključne riječi: jezični stereotipi, spolno/rodno neutralan jezik, spolno/rodno obilježen jezik, jezik koji ima prirodni rod, jezik koji ima gramatički rod, mocijski parnjaci

Keywords: language stereotypes, gender-fair language, sexist language, natural gender language, grammatical gender language, male-female pairs 